\title{
Childhood Supratentorial Ependymoma
}

National Cancer Institute

\section{Source}

National Cancer Institute. Childhood Supratentorial Ependymoma. NCI Thesaurus. Code C9043.

An ependymoma that arises from the supratentorial region of the brain and occurs during childhood. 